\title{
REFORMASI KEKUASAAN MENGADILI PENGADILAN AGAMA BERDASARKAN UNDANG-UNDANG NOMOR 50 TAHUN 2009 TENTANG PERUBAHAN ATAS UNDANG-UNDANG NOMOR 3 TAHUN 2006 TENTANG PERADILAN AGAMA
}

\author{
Arini Indika Arifin \\ Program Pascasarjana Magister Ilmu Agama Islam, Fakultas Ilmu Agama Islam \\ Universitas Islam Indonesia \\ Email : ariniindika@gmail.com
}

\section{Abstract}

The competence of the Religious Courts has undergone considerable dynamics and leads to the ups and downs. Although not until abolished, but the scope of jurisdiction of religious courts is often limited to certain civil cases. This fact is in fact inseparable from the political will of the rulers of their time reflected in the policies pursued by the authorities concerned. It is undeniable that the political dynamics of law and the political will of the rulers from time to time have drawn important notes for the existence, position, and authority of religious courts in Indonesia, which in reality are not always on a relatively smooth journey.

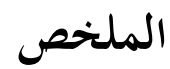

شهدت المحكمة الشرعية كفاءة ديناميكية معقدة إلى حد ما وتؤدي إلى الصعود والهبوط. وإن لم يكن ليتم القضاء لكن في نطاق اختصاص المحكمة الشرعية يقتصر ذلك النطاق في قضايا مدنية معينة غالبا. هذه الحقيقة ليست مستقلة عن إرادة السلطان السياسية في عصره التي تنعكس في السياسات المستخدمة من قبل السلطان نفسه. مما لا شك فيه أن عامل الديناميات السياسية القانونية وإرادة السلطان السياسية من وقت إلى وقت نحت سجلا هاما لوجود وموقف وسلطة المحكمة 

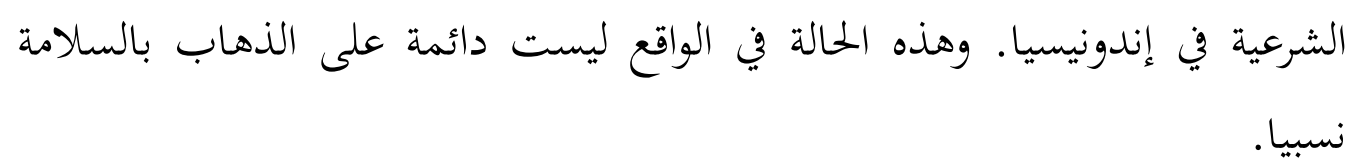

Keywords: Peradilan Agama, Political will, Politik Hukum

\section{A. Pendahuluan}

Keberadaan lembaga peradilan agama di Indonesia adalah merupakan kebutuhan masyarakat Indonesia yang beragama Islam dalam melaksanakan ajaran agamanya yang berupa hukum Islam. Dalam konsepsi ilmu fikih, masalah peradilan atau al-qadla' merupakan kewajiban kolektif atau fardhu kifayah yang disamakan dengan fardhu kifayah lainnya, seperti mendirikan jama'ah dan shalat jama'ah, menyelenggarakan kesejahteraan umum dan mencegah kemungkaran. ${ }^{1}$

Perkembangan hukum ketatanegaraan Indonesia yang diawali oleh adanya amandemen Undang-undang Dasar 1945, menuntut adanya perubahan pada berbagai peraturan perundang-undangan. Perubahan Pasal 24 ayat (1) Undang-Undang Dasar Negara Republik Indonesia Tahun 1945 menegaskan bahwa kekuasaan kehakiman merupakan kekuasaan yang merdeka² untuk menyelenggarakan peradilan guna menegakkan hukum dan keadilan. Pasal

1 Ali Irfan, Sejarah, Peran dan Kewenangan Peradilan dalam penegakan Hukum Islam di Indonesia, makalah disampaikan pada seminar nasional dan call for papers "perkembangan Hukum Islam di Indonesia, Penyelenggara bagian Hukum Perdata Fakultas Hukum Universitas Diponegoro Semarang, tanggal 19 September 2012, hal. 182.

2 Dikatakan merdeka karena memperhatikan perjalanan sejarah kenegaraan Republik Indonesia, perkembangan pemikiran dan praktik mengenai prinsip-prinsip negara hukum diakui mengandung kelemahan, yakni hukum menjadi alat bagi kepentingan penguasa. Kekuasaan kehakiman merupakan kekuasaan yang merdeka untuk menyelenggarakan peradilan guna menegakkan hukum dan keadilan, terlepas dari pengaruh kekuasaan pemerintah, seperti dikehendaki Pasal 24 UUD 1945. Hal ini berarti kekuasaan kehakiman yang merdeka atau independensi kekuasaan kehakiman, telah diatur secara konstitusional dalam UUD 1945. Dari konsep negara hukum seperti yang digariskan oleh konstitusi, maka dalam rangka melaksanakan Pasal 24 UUD 1945, harus secara tegas melarang kekuasaan pemerintahan negara (eksekutif) untuk membatasi atau mengurangi wewenang kekuasaan kehakiman yang merdeka yang telah dijamin oleh konstitusi tersebut. Dengan demikian kekuasaan kehakiman yang merdeka terlepas dari pengaruh kekuasaan pemerintah, sebagai upaya untuk menjamin dan melindungi kebebasan rakyat dari kemungkinan tindakan sewenang-wenang dari pemerintah. 
24 ayat (2) Undang-Undang Dasar Negara Republik Indonesia Tahun 1945 menentukan bahwa kekuasaan kehakiman dilakukan oleh sebuah Mahkamah Agung dan badan peradilan di bawahnya dalam lingkungan peradilan umum, lingkungan peradilan agama, lingkungan peradilan militer, lingkungan peradilan tata usaha negara, dan oleh sebuah Mahkamah Konstitusi.

Amandemen Undang-Undang Dasar 1945 ini menuntut adanya perubahan semua Undnag-undang tentang kekuasaan peradilan pada 4 lingkungan peradilan serta peraturan lain yang berkaitan dengan kekuasaan kehakiman. Undang-Undang Nomor 4 Tahun 2004 tentang Kekuasaan Kehakiman sudah mengalami perubahan karena adanya Putusan Mahkamah Konstitusi Nomor 005/PUU-IV/ 2006 tanggal 23 Agustus 2006, di mana dalam putusannya tersebut telah menyatakan Pasal 34 ayat (3) Undang-Undang Nomor 4 Tahun 2004 tentang Kekuasaan Kehakiman dan ketentuan pasal-pasal yang menyangkut mengenai pengawasan hakim dalam Undang-Undang Nomor 22 Tahun 2004 tentang Komisi Yudisial bertentangan dengan Undang-Undang Dasar Negara Republik Indonesia Tahun 1945 dan karenanya tidak mempunyai kekuatan hukum mengikat. ${ }^{3}$

Sebagai konsekuensi logis-yuridis dari putusan Mahkamah Konstitusi tersebut, telah dilakukan perubahan atas Undang-Undang Nomor 14 Tahun 1985 tentang Mahkamah Agung sebagaimana telah diubah dengan Undangundang Nomor 5 Tahun 2004 tentang perubahan atas Undang-Undang Nomor 14 Tahun 1985 tentang Mahkamah Agung dan Undang-Undang Nomor 3 Tahun 2009 tentang Perubahan Kedua Atas Undang-Undang Nomor 14 Tahun 1985 tentang Mahkamah Agung, selain Undang-Undang Nomor 22 Tahun 2004 tentang Komisi Yudisial itu sendiri yang terhadap beberapa pasalnya telah dinyatakan tidak mempunyai kekuatan hukum yang mengikat.

Undang-Undang Nomor 7 Tahun 1989 tentang Peradilan Agama, merupakan salah satu undang-undang yang mengatur lingkungan peradilan yang berada di bawah Mahkamah Agung. Dalam upaya penyesuaian atau sinkronisasi terhadap Undang-Undang Nomor 3 Tahun 2009 tentang Perubahan Kedua Atas Undang-Undang Nomor 14 Tahun 1985 tentang Mahkamah Agung dan perubahan atas Undang-Undang Nomor 22 Tahun 2004 tentang Komisi

3 Linda Firdawaty, Analisis tentang perubahan undang-undang Peradilan Agama, dalam jurnal AL-'adalah vol. x, no. 2 juli 2011 hlm 213. 
Yudisial, Undang-undang tentang Peradilan Agama ini juga telah mengalami perubahan.

Tulisan ini akan menganalisis beberapa perubahan yang substansial mengenai kekuasaan mengadili Pengadilan Agama setelah adanya amandemen pertama dan kedua Undang-Undang No 7 Tahun 1989 tentang Peradilan Agama yang diatur menurut Undang-undang Nomor 3 Tahun 2006 dan UndangUndang Nomor 50 Tahun 2009.

\section{B. Lahirnya Pengadilan Agama di Indonesia}

Pada masa awal pasca kemerdekaan Indonesia, teori receptie ternyata masih menguasai alam pikiran dari para sarjana hukum Indonesia, khususnya yang ada di legislatif maupun yang ada di yudikatif. Hal ini nampak dengan berlakunya hukum adat dalam kerangka hukum nasional, yakni berlakunya hak hak masyarakat adat (hak ulayat) sebagaimana yang diatur dalam UU No. 5 tahun 1960 tentang Peraturan Dasar Pokok Pokok Agraria (UUPA). Pada kenyataannya masih tampak nyata bahwa seolah-olah hukum Islam yang berlaku di masyarakat baru berlaku jika hukum adat telah menerimanya Pada awal tahun 1946, tepatnya tanggal 3 Januari 1946, dibentuklah Kementrian Agama. Departemen Agama dimungkinkan melakukan konsolidasi atas seluruh administrasi lembaga lembaga Islam dalam sebuah badan yang bersifat nasional. Berlakunya UU No. 22 tahun 1946 menunjukkan dengan jelas maksud maksud untuk mempersatukan administrasi Nikah, Talak, dan Rujuk di seluruh Indonesia di bawah pengawasan Departemen Agama sendiri.

Pada masa ini, Pengadilan Agama dan Mahkamah Islam Tinggi yang telah ada tetap berlaku berdasarkan Aturan Peralihan. Selang tiga bulan berdirinya Departemen Agama yang dibentuk melalui Keputusan PemerintahNomor 1/SD, Pemerintah mengeluarkan penetapan No. 5/SD tanggal 25 Maret 1946 yang memindahkan semua urusan mengenai Mahkamah Islam Tinggi dari Departemen Kehakiman kepada Departemen Agama. Sejak saat itulah peradilan agama menjadi bagian penting dari Departemen Agama. Setelah Pengadilan Agama diserahkan pada Departemen Agama, masih ada sementara pihak tertentu yang berusaha menghapuskan keberadaan Pengadilan Agama.

Usaha pertama dilakukan melaui Undang undang Nomor 19 Tahun 1948. Usaha kedua melalui Undang Undang Darurat Nomor 1 Tahun 1951 
tentang Susunan Kekuasaan Peradilan Sipil. Usaha usaha yang mengarah kepada penghapusan Pengadilan Agama ini menggugah minat untuk lebih memperhatikan Pengadilan Agama. Pengadilan Agama selanjutnya ditempatkan di bawah tanggung jawab Jawatan Urusan Agama. Penempatan Pengadilan Agama di bawah Departemen Agama merupakan langkah yang menguntungkan sekaligus sebagai langkah pengamanan, karena meskipun Indonesia merdeka, namun pengaruh teori receptie yang berupaya untuk mengeliminir Peradilan Agama masih tetap hidup. Hal ini terbukti dengan lahirnya Undang Undang Nomor 19 Tahun 1948 yang menyatakan bahwa Peradilan Agama akan dimasukkan secara istimewa dalam susunan Peradilan Umum, yaitu bahwa perkara perkara antara orang Islam yang menurut hukum yang hidup (living law) harus diputus menurut hukum Islam, harus diperiksa oleh badan Peradilan Umum dalam semua tingkatan Peradilan, terdiri dari seorang hakim yang beragama Islam sebagai ketua dan dua hakim ahli agama Islam sebagai anggota, yang diangkat oleh presiden atas usul Menteri Agama dengan persetujuan Menteri Kehakiman. Kemudian pada tanggal 31 Oktober 1964 disahkan UU No. 19 tahun 1964 tentang Ketentuan Pokok Pokok Kekuasaan Kehakiman. ${ }^{4}$

Menurut undang undang ini, Peradilan Nergara Republik Indonesia menjalankan dan melaksanakan hukum yang mempunyai fungsi pengayoman yang dilaksanakan dalam lingkungan Peradilan Umum, Peradilan Agama, Peradilan Militer, dan Peradilan Tata Usaha Negara. Namun tidak lama kemudian, undang undang ini diganti dengan UU No. 14 tahun 1970 tentang Ketentuan Ketentuan Pokok Pokok Kehakiman karena sudah dianggap tidak sesuai lagi dengan keadaan. Dalam undang undang baru ini ditegaskan bahwa Kekuasaan Kehakiman adalah kekuasaan yang merdeka. Ditegaskan demikian karena sejak tahun 1945-1966 keempat lingkungan peradilan di atas bukanlah kekuasaan yang merdeka secara utuh, melainkan di sana sini masih mendapat intervensi dari kekuasaan lain.

Undang Undang Nomor 14 tahun 1970 merupakan undang undang organik, sehingga perlu adanya undang undang lain sebagai peraturan pelaksananya, yaitu undang undang yang terkait dengan Peradilan Umum, Peradilan Militer,

4 Abdul Ghofur Anshori, Peradilan Agama di Indonesia Pasca UU No. 3 Tahun 2006; Sejarah, Kedudukan, dan Kewenangan. (Yogyakarta: UII Press,2007), Hal. 12. 
Peradilan tata Usaha Negara, termasuk juga PeradilanAgama. Namun secara faktual dapat dilihat bahwa pengundangan undang-undang Peradilan Agama adalah yang terakhir dibanding dengan undang undang Peradilan yang lain, yaitu tepatnya 19 tahun setelah Undang Undang Pokok Kekuasaan Kehakiman disahkan. Oleh karena itu, hingga tahun 1989, tepatnya sampai disahkan Undang Undang Nomor 7 Tahun 1989 tentang Peradilan Agama, Peradilan Agama masih belum bisa disebut sebagai Peradilan yang sesungguhnya, karena Peradilan Agama belum diberi wewenang untuk menjalankan keputusan yang dibuatnya sendiri, melainkan Pengadilan Agama hanya dapat mengimplementasikan keputusannya apabila sudah mendapat restu atau izin dari Pengadilan Negeri dalam bentuk executoir verklaring. Barulah kemudian setelah disahkannya Undang Undang Nomor 7 Tahun 1989 tersebut, Peradilan Agama sudah diberi wewenang untuk menjalankan keputusan yang dibuatnya sendiri.

Di Era Orde Baru, usaha untuk mengurangi dan mengeliminir, bahkan menghapuskan baik wewenang maupun peran Peradilan Agama pernah terjadi ketika RUU Perkawinan dibuat oleh pemerintah dan diajukan ke DPR pada tahun 1973. Rancangan undang undang tersebut memiliki dua tujuan. Pertama, untuk mengurangi frekuensi perceraian dan perkawinan di bawah umur. Kedua, untuk menyeragamkan undang undang perkawinan di Indonesia sebagai bagian program kesatuan dan persatuan Indonesia di bawah idiologi negara Pancasila. ${ }^{5}$ Dalam RUU tersebut, Peradilan Agama hanya disebut dalam rancangan penjelasan pasal73 ayat (2). Bunyirancangan penjelasan pasal tersebut adalah sebagai berikut: Untuk memperlancar pelaksanaan undang undang ini, Pemerintah dapat mengatur lebih lanjut hal hal tertentu yang memerlukan ketentuan pelaksanaan, antara lain yang bersangkut paut pengikutsertaan Pengadilan Agama dalam tata cara penyelesaian perselisihan perkawinan dan perceraian oleh Pengadilan Umum, tata cara berlangsungnya perkawinan sebagai golongan bagi agama Islam adanya saksi, wali dan sebagainya.

Peletakkan kata Pengadilan Agama pada penjelasan segera dapat dibaca bahwa Pengadilan Agama hanyalah pelengkap Pengadilan Umum. Penjelasan bukanlah bagian dari undang undang dan tidak dapat dijadikan sebagai dasar

5 Sidiq Tono. "Perkembangan Peradilan di Indonesia: Studi Politik Hukum”, Jurnal Al Mawarid. Edisi VI Desember 1997. (Yogyakarta: Fakultas Ilmu Agama Islam), hal. 77. 
penyelenggaraan proses peradilan (dasar hukum). Karena itu, maka dipahami bahwa RUU tersebut dinilai sebagai upaya untuk menghapuskan Pengadilan Agama. Posisi pelengkap itu pun, oleh RUU direkomendasikan pada Peraturan Pemerintah (PP). Secara harfiah dapat dimengerti status Pengadilan Agama menurut RUU tersebut akan berada di bawah wewenang Pengadilan Umum. Pasal 3 ayat 2 RUU berbunyi: Pengadilan dalam lingkungan Peradilan Umum, selanjutnya dalam undang undang ini disebut Pengadilan dapat memberi izin kepada seorang suami untuk beristri lebih dari seorang apabila dikehendaki oleh pihak pihak yang bersangkutan. Dari bunyi pasal 3 ayat 2 dan penjelasan pasal 73 ayat 2 di atas terlihat bahwa akan terjadi pengalihan wewenang masalah perkawinan dari Pengadilan Agama kepada Pengadilan Negeri. Pengadilan Agama akan diikutsertakan dalam persoalan ini sepanjang menyangkut tata cara berlangsungnya perkawinan. Jika ini terjadi, maka habislah sudah wewenang Peradilan Agama karena masalah kewarisan dan harta benda sudah dicabut terlebih dahulu oleh staatsblad 1937 No. 116.

Tetapi akhirnya masyarakat muslim bisa bernafas lega, sebab biarpun melalui perjuangan yang amat berat, yaitu dengan persetujuan dan kompromi umat Islam, akhirnya RUU Perkawinan di atas diamandemen dan pada bulan Januari 1974 disahkan menjadi UU No. 1 tahun 1974 tentang Perkawinan. Dengan itu, maka keberadaan Peradilan Agama menjadi terselamatkan, namun perannya tetap dibatasi. Pembatasan yang dimaksud terletak pada ketentuan pasal 63 ayat 2 UU No. 1 tahun 1974 tersebut yang mengatakan bahwa "setiap keputusan Pengadilan Agama dikukuhkan oleh Pengadilan umum." Dengan ketentuan ini, maka Peradilan Agama masih tetap diposisikan sebagai Peradilan "Pupuk Bawang". Terlepas dari itu semua, harus diakui bahwa UU No. 1 tahun 1974 ini sangat berati dalam perkembangan Peradilan Agama di Indonesia, karena selain menyelamatkan keberadaan Peradilan Agama sendiri, sejak disahkan UU No. 1 tahun 1974 tentang Perkawinan jo. PP No. 9 tahun 1975 tentang Peraturan Pelaksananya, maka terbit pula lah ketentuan Hukum Acara di Pengadilan Agama, biarpun baru sebagian kecil saja. Ketentuan Hukum Acara yang berlaku di lingkungan Peradilan Agama baru disebutkan secara tegas sejak diterbitkan UU No. 7 tahun 1989 tentang Peradilan Agama.

Hukum Acara yang dimaksud diletakkan pada ketentuan Bab IV yangterdiri dari 37 pasal. Memang tidak semua ketentuan tentang Hukum Acara Peradilan Agama dimuat dalam undang undang ini. Hal itu dapat dilihat dalam pasal 
54, dimana dikemukakan bahwa Hukum Acara yang berlaku pada Pengadilan dalam lingkungan Peradilan Agama adalah Hukum Acara Perdata yang berlaku pada Pengadilan dalam lingkungan Peradilan Umum, kecuali yang telah diatur secara khusus dalam undang undang ini. ${ }^{6}$ Oleh karena itu, disamping Hukum Acara Perdata yang terdapat dalam HIR dan RB.g. terdapat pula beberapa pasal ketentuan yang berisi Hukum Acara Perdata sepanjang pasal pasal yang tercantum dalam bab IV tersebut. ${ }^{7}$

Dalam perjalanannya, penolakan penolakan terhadap legalisasi Peradilan Agama pada masa ini masih gencar. Hal ini nampak pada pembahasan RUU No. 7 tahun 1989 tentang Peradilan Agama oleh DPR. Sebagian masyarakat, kebanyakan dari unsur agama katolik menuduh bahwa penegakkan RUU tersebut berarti penegakkan kembali Piagam Jakarta. S. Wijoyo misalnya secara terang-terangan mengatakan bahwa RUU tersebut menentang kesaktian Pancasila. Sedangkan R. Suprapto menyatakan bahwa keberadaan Peradilan Agama tidak dapat diterima karena penerimaan Peradilan Agama sama dengan menerima sumber di luar UUD 1945 dan Pancasila. Selain itu dia juga mengusulkan agar UU No. 14 tahun 1970 ditinjau kembali. Terlepas dari gencarnya pro dan kontra perihal pengesahan UU No. 7 tahun 1989 di atas, bahkan tak kurang dari empat ratus artikel tentang tanggapan pro dan kontra tersebut dimuat di media masa, namun akhirnya pada tanggal 27 Desember 1989 UU No. 7 tahun 1989 tentang Peradilan Agama disahkan oleh DPR yang kemudian diikuti dengan dikeluarkannya Inpres No. 1 tahun 1991 tentang Kompilasi Hukum Islam. Dengan disahkan UU tersebut bukan saja menyejajarkan kedudukan Peradilan Agama dengan lembaga peradilan peradilan lain, melainkan juga mengembalikan kompetensi Peradilan Agama yang dulu pernah dimilikinya pada zaman kolonial.

Secara singkat dapat diketahui terdapat beberapa peraturan perundangundangan mengenai Pengadilan Agama sebelum di bentuk undang-undang Pengadilan Agama nomor 7 tahun 1989, yang akan diuraikan sebagai berikut:

a. Instruksi pemerintah Hindia Belanda pada bulan September 1861 kepada para bupati yang berisi jaminan terhadap pelaksanaan urusan agama bagi

6 Abdul Manan, Penerapan Hukum Acara Perdata di Lingkungan Peradilan Agama. (Jakarta: Prenada Media. 2005), Hal. 7.

7 Sulaikin Lubis dkk, Hukum Acara Perdata Peradilan Agama di Indonesia. (Jakarta: Prenada Media. 1995), Hal. 75. 
orang Jawa dan kewenangan untuk memutus sendiri perkara-perkara tertentu dalam bidang perkawinan dan kewarisan.

b. Stbl No. 22 pasal 13 Tahun 1820 berisi perintah kepada bupati agar memerhatikan soal-soal agama Islam dan membiarkan para pemuka agama melakukan tugas mereka sesuai dengan adat kebiasaan orang Jawa, khususnya mengenai perkawinan, pembagian pusaka dan perkara sejenis.

c. Resolusi Gubernur Jenderal No. 12 Tanggal 3 Juni 1823 tentang peresmian pengadilan agama di kota Palembang

d. Regeerings Reglement (RR) 1854 (Stbl 1855, No 2) tentang pembatasan Kewenangan Pengadilan Agama berisi bahwa pengadilan agama tidak berwenang mengadili masalah pidana dan kewenangannya didasarkan pada hukum-hukum agama atau adat-adat lama.

e. RR 1854 Pasal 109 isinya memperluas berlakunya peradilan agama bagi sesama orang Arab, sesama orang Moor, sesama orang Cina, sesama orang India, dan sesama orang Malaya yang beragama Islam. ${ }^{8}$

f. Setelah Indonesia merdeka, berlaku tiga ketentuan sebagai berikut.

1) Stbl 1882 No. 152 jo stbl 1937 N0. 116 dan 610 tentang Peradilan Agama di Jawa dan Madura.

2) Stbl 1937 No. 638 dan 639 tentang Peradilan Agama di Kalimantan Selatan.

3) Peraturan Pemerintah No. 45 Tahun 1957 tentang Peradilan Agama di luar Jawa dan Kalimantan Selatan.

4) Undang-Undang Nomor 14 tahun 1970 tentang kekuasaan kehakiman yang memperkuat keberadaan lembaga Peradilan Agama

5) Undang-Undang Nomor 7 tahun 1989 tentang Peradilan Agama, yang kemudian disusul dengan lahirnya Undang-Undang Nomor 3 tahun 2006 tentang perubahan atas Undang-Undang Nomor 7 tahun 1989, dan terakhir dengan lahirnya Undang-Undang Nomor 50 tahun 2009.9

\section{Kekuasaan Relatif}

Kompetensi Relatif artinya kekuasaan pengadilan dalam satu jenis dan sama tingkatan, perbedaannya dengan pengadilan lain yang sama jenis dan

8 Warkum Sumitro, Perkembangan Hukum Islam di tengah Kehidupan sosial politik di Indonesia, (Malang, Bayu Media Publishing, 2005), hal. 159.

$9 \quad$ Ibid. 
tingkatannya.Dapat diartikan Kompetensi Relatif adalah kekuasaan pengadilan yang dibatasi oleh wilayah hukum. Masing-masing badan peradilan berwenang mengadili perkara yang menjadi kekuasaannya berdasarkan wilayah hukum. Pasal 4 ayat (1) UU Nomor 7 Tahun 1989 berbunyi:

Pengadilan Agama berkedudukan di Kotamadya atau di ibu kota kabupaten, dan daerah hukumnya meliputi wilayah kotamadya atau kabupaten. Penjelasan Pasal 4 ayat (1) ini berbunyi: "Pada dasarnya tempat kedudukan Pengadilan Agama ada di kota madya atau ibu kota kabupaten yang daerah hukumnya meliputi wilayah kotamadya atau kabupaten, tetapi tidak tertutup kemungkinan adanya pengecualian". Arti penting Kompetensi relative ini adalah untuk mengetahui ke Pengadilan Agama yang mana orang akan mengajukan perkaranya dan hubungannya dengan hak eksepsi tergugat. ${ }^{10}$ Secara umum, dapat dikatakan bahwa pengadilan negeri memiliki wewenang relatif untuk menerima, memeriksa, dan mengadili, serta menyelesaikan perkara yang tergugatnya bertempat tinggal (berdomisili) di daerah hukumnya.

Secara khusus dan terperinci Pasal 118 HIR/ 142 Rbg mengatur tentang kewenangan (kekuasaan relatif) dari Pengadilan Negeri. Menurut Pasal 118 HIR pada asasnya gugatan harus diajukan ke Pengadilan Negeri tempat tinggal tergugat. Asas ini dalam bahasa Latin dikenal dengan sebutan asas Actor Sequitor Forum Rei. Terhadap asas Actor Sequitor Forum Rei, terdapat beberapa pengecualian, antara lain:

a) Apabila tempat tinggal tergugat tidak diketahui, maka gugatan diajukan ke Pengadilan Negeri tempat kediaman penggugat.

b) Apabila tergugat terdiri dari dua orang atau lebih, dan mereka tinggal pada tempat yang berlainan, maka gugatan dapat diajukan pada tempat tinggal salah seorang tergugat.

c) Apabila yang digugat itu terdiri dari orang-orang berutang dan penanggung/ penjamin, maka gugatan diajukan kepada Pengadilan Negeri di tempat orang yang berutang.

d) Apabila tempat tinggal dan tempat kediaman atau orang yang digugat tidak diketahui atau tidak dikenal, maka gugatan diajukan ke Pengadilan Negeri tempat tinggal Penggugat.

10 Royhan A. Rasyid, Hukum Acara Peradilan Agama, (Jakarta: Raja Grapindo Persada, 1992), hal. 25. 
e) Dalam hal keadaan nomor diatas, apabila gugatannya mengenai barang tetap (barang tidak bergerak), maka gugatannya diajukan ke Pengadilan tempat dimana barang tetap (tidak bergerak) tersebut berada. Asas ini dikenal dengan sebutan Actor Sequitor Forum Sitei. Jika benda tetap tersebut terletak dalam beberapa daerah hukum Pengadilan Agama, maka gugatan diajukan kepada salah satu pengadilan Agama menurut pilihan penggugat.

f) Kalau kedua belah pihak memilih tempat tinggal khusus dengan akta yang tertulis, maka penggugat kalau mau dapat mengajukan gugatan kepada Pengadilan Negeri di tempat yang telah dipilih dalam akta tersebut. ${ }^{11}$

Teori umum hukum perdata menentukan bahwa kompetensi relatif suatu peradilan merujuk pada ketentuan dalam Pasal 118 HIR, Pasal 142 RBg, serta Pasal 99 Rv. Khusus mengenai kompetensi relatif Pengadilan Agama, yang berkaitan dengan cerai gugat, mengacu pada ketentuan dalam Pasal 73 ayat 2 Undang-Undang Nomor 7 tahun 1989 jo Pasal 132 Kompilasi Hukum Islam. Adapun kompetensi relatif yang berkaitan dengan permohonan cerai talak, mengacu pada ketentuan Pasal 66 ayat 2, 3 dan 4 Undang-Undang Nomor 7 tahun 1989 jo Pasal 129 Kompilasi Hukum Islam.

Ketentuan Pasal 66 Undang-Undang Nomor 7 tahun 1989 tersebut mengatur kompetensi relatif dalam bentuk permohonan cerai talak. Prinsip dasar kompetensi relatif dalam perkara cerai talak adalah bahwa permohonan cerai talak diajukan di Pengadilan Agama yang mewilayahi tempat kediaman termohon (istri). Hal ini merupakan penegasan dari Pasal 118 HIR/142 $\mathrm{RBg}$, yang telah melahirkan asas umum actor sequitor forum rei. Pengajuan permohonan hanya dapat menyimpang dari prinsip dasar, atau permohonan diajukan kepada Pengadilan Agama yang mewilayahi tempat tinggal Pemohon apabila memenuhi alasan pengecualian sebagaimana dalam Pasal 66 ayat 2, 3 dan 4 Undang-Undang nomor 7 tahun 1989. ${ }^{12}$

11 M. Nur Rasaid, Hukum Acara Perdata, (Jakarta: Sinar Grafika, 1996), hal. 21.

12 Neng Yani Nurhayani, Hukum Acara Perdata, (Bandung: Pustaka Setia, 2015), hal. 81. 


\section{E. Reformasi Kekuasaan Mengadili Pengadilan Agama Berdasarkan Amandemen Terakhir Undang-undang nomor 50 tahun 2009 ten- tang Pengadilan Agama}

Pada tanggal 28 Februari 2006, Undang-Undang No. 7 tahun 1989 tentang Peradilan Agama telah diamandemen dengan Undang-Undang No. 3 tahun 2006 tentang perubahan atas UU No. 7 tahun 1989 (Lembaran Negara Republik Indonesia tahun 2006 Nomor 22). Perubahan tersebut dilakukan karena UndangUndang no. 7 tahun 1989 tidak sesuai lagi dengan perkembangan kebutuhan hukum masyarakat dan kehidupan ketatanegaraan menurut UUD 1945. Sesuai amanat konstitusi pasal 24 ayat (2), bahwa Peradilan Agama merupakan salah satu lingkungan peradilan yang berada di Mahkamah Agung bersama Peradilan lainnya di lingkungan Peradilan umum, Peradilan tata usaha negara dan Peradilan militer. Begitu juga ketentuan Pasal 10 ayat 2 Undang-Undang no. 4 tahun 2004 tentang Kekuasaan Kehakiman, bahwa badan peradilan yang berada di Mahkamah Agung meliputi badan peradilan dalam lingkungan Peradilan Umum, Peradilan Agama, Peradilan Militer, danPeradilan tata usaha negara. Oleh karena itu berlaku kebijakan satu atap (the one roof system). Pemberlakuan the one roof system secara tegas mengatur pengalihan organisasi, administrasi, finansial dari semua lingkungan peradilan ke Mahkamah Agung. Dengan demikian, organisasi, administrasi, finansial Pengadilan Agama yang sebelumnya berada di bawah Departemen Agama beralih ke Mahkamah Agung. ${ }^{13}$

Kewenangan Peradilan Agama yang semula bertugas dan berwenang memeriksa,memutus, dan menyelesaikan perkara-perkara tingkat pertama antara orang-orang yang beragama Islam di bidang: a. Perkawinan, b. Kewarisan, wasiat dan hibah, c. Waqaf dan Shadaqah. Berdasarkan UndangUndang no. 3 tahun 2006 kewenangannya diperluas dalam bidang ekonomi syari'ah meliputi: Bank Syari'ah, Asuransi Syari'ah, Reasuransi Syari'ah, Surat Berharga Menengah syari'ah, Sekuritas Syari'ah, Dana Pensiun Lembaga Keuangan (DPLK) Syari'ah, Bisnis Syari'ah, dan Lembaga Keuangan Mikro Syari'ah.

Dalam perkara ekonomi syariah belum ada pedoman bagi hakim dalam menyelesaikan sengketa ekonomi syariah. Untuk memperlancar proses

13 Mardani, Hukum Islam, (Yogyakarta: Pustaka Pelajar, 2015), hlm, 151. 
pemeriksaan dan penyelesaiansengketa ekonomisyariah, dikeluarkan Peraturan Mahkamah Agung Nomor 2 Tahun 2008 tentang Peraturan Mahkamah Agung Republik Indonesia tentang Kompilasi Hukum Ekonomi Syariah.

Pasal 1 PERMA tersebut menyatakan bahwa:

1) Hakim pengadilan dalam lingkungan peradilan agama yang memeriksa, mengadili dan menyelesaikan perkara yang berkaitan dengan ekonomi syariah, mempergunakan sebagai pedoman prinsip syariah dalam Kompilasi Hukum Ekonomi Syari'ah.

2) Mempergunakan sebagai pedoman prinsip syariah dalam Kompilasi Hukum Ekonomi Syari'ah sebagaimana dimaksud ayat (1), tidak mengurangi tanggung jawab hakim untuk menggali dan menemukan hukum untuk menjamin putusan yang adil dan benar. ${ }^{14}$

Kewenangan Peradilan Agama menangani sengketa ekonomi syariah juga diatur dalam UU No. 21 tahun 2008 tentang Perbankan syariah sebagaimana diatur dalam Pasal 55, sebagai berikut:

1) Penyelesaian sengketa Perbankan Syari'ah dilakukan oleh Pengadilan dalam lingkungan Peradilan Agama.

2) Dalam hal para pihak telah memperjanjikan penyelesaian sengketa selain sebagaimana yang dimaksud pada ayat 1 penyelesaian dilakukan sesuai dengan isi akad.

3) Penyelesaian sengketa sebagaimana dimaksud pada ayat 2 tidak boleh bertentangan dengan prinsip syari'ah.

Dalam penjelasan Pasal 55 ayat 2 berbunyi yang dimaksud dengan penyelesaian sengketa dilakukan sesuai dengan isi akad adalah upaya musyawarah, mediasi perbankan, melalui Badan Arbitrase Syari'ah Nasional, atau lembaga arbitrase lain.

Kemudian berdasarkan Pasal 49 UU Nomor 3 Tahun 2006, Peradilan Agama merupakan satu-satunya lembaga peradilan yang berwenang menangani sengketa ekonomi syariah termasuk di dalamnya perbankan syariah, akan tetapi dalam UU No. 21 tahun 2008 sebagaimana ketentuan dalam Pasal 55 ayat 2, lembaga yang berwenang menangani sengketa perbankan syari'ah sesuai dengan isi akad bukan hanya peradilan agama melainkan pengadilan dalam lingkungan peradilan umum disamping melalui musyawarah, mediasi

\footnotetext{
14 Ibid Linda, Analisis...,hal. 220.
} 
perbankan, melalui Badan Arbitrase Syariah atau lembaga arbitrase lain, dan/ atau melalui pengadilan dalam lingkungan peradilan umum. ${ }^{15}$

Penjelasan inilah yang kemudian memancing lahirnya kesimpulan bahwa rumusan hukum pasal 52 UUPS, selain menyisakan problematika pada level hukum materiil, juga dianggap sebagai pasal yang memuat materi yang bersifat ambigu.

Dalam konteks ini, Abdul Ghani Abdullah memberikan beberapa catatan terkait dengan Penjelasan Pasal 55 ayat 2 UUPS. Pertama, apabila rumusan pasal tersebut dibaca dengan scanning reading, sudah mengandung kesan yuridis bahwa secara keseluruhan proses penyelesaian sengketa perbankan syariah pada prinsipnya dilakukan oleh Pengadilan Agama. Hal ini sejalan dengan rumusan pada ayat 1 bahwa penyelesaian sengketa perbankan syariah dilakukan oleh pengadilan dalam lingkungan peradilan agama.

Kedua, apabila rumusan tersebut dibaca dengan substansial and connecting reading, mengandung kesan bahwa antara ayat 1 dan ayat 2 terdapat makna normatif yang contradictio in terminis, yaitu makna normatif dalam muatan ayat 1 dan ayat 2 saling bertentangan, karena di dalam penjelasan ayat 2 diatur ketentuan bahwa salah satu upaya penyelesaian sengketa yang dapat diperjanjikan adalah secara alternatif melalui pengadilan dalam peradilan umum. Dengan demikian, pengadilan dalam lingkungan perdilan agama pada ayat 1 itu bukanlah klausul mutlak, karena di buat sedemikian rupa sehingga berdasarkan klausul hukum di dalam huruf D pada ayat 2 menjadikannya sebagai forum alternatif seperti halnya posisi pengadilan dalam peradilan umum dan arbitrase.

Ketiga, dalam hal masyarakat pencari keadilan mengadakan perjanjian dengan memilih memuat adanya klausul arbitrase, maka baik pengadilan dalam lingkungan dalam peradilan agama maupun pengadilan dalam peradilan umum menjadi tidak berwenang.

Berdasarkan uraian di atas, dapat dikatakan bahwa pasal 55 ayat 2 UUPS sesungguhnya memperlihatkan bahwa nuansa politik hukum pemerintah sebagai pengusul masih di pengaruhi oleh paradigma politik hukum kolonial. Padahal politik hukum pemerintah adalah kebijakan hukum atau (legal policy)

15 Ali Irfan, Perkembangan Hukum Islam dan Permasalahan penegakannya di Indonesia, Prosiding Seminar, Pustaka Magister Semarang, Semarang, hal. 190. 
yang hendak dilaksanakan secara nasional, antara lain adalah dalam rangka pembangunan hukum yang berintikan pembuatan hukum dan pembaruan terhadap badan - badan hukum yang di anggap tidak relefan dengan kebutuhan penciptaan hukum yang tepat. Di samping itu, usulan pemerintahan yang telah disahkan itu telahterlalu jauh mencampuri ranah yudikatif, sebab penyelesaiaan perkara ekonomi syariah sebelumnya telah diberikan kepada peradilan agama melalui undang - undang peradilan agama.

Muatan Pasal 55 Ayat 2 UUPS faktualnya sangat bertentangan secara horizontal dengan UU No. 3 Tahun 2006 tentang Peradilan Agma, karena secara yuridis tidak sinkron dan konsisten dengan peraturan perundang-undangan yang berlaku. Hal ini mengingat bahwa persoalan penyelesaian sengketa ekonomi syariah, termasuk perbankan syariah, melalui jalur litigasi sudah diatur dalam UU No. 3 tahun 2006, yakni menjadi kompetensi absolut pengadilan agama. Dengan demikian, kewenangan peradilan agama dalam menangani sengketa ekonomi syariah, termasuk salah satunya ihwal perbankan syari'ah telah ditetapkan secara filosofis akan selaras antara hukum yang berlandaskan prinsip-prinsip Islam dengan lembaga peradilan yang merupakan representasi lembaga peradilan Islam, dan juga selaras dengan para aparat hukumnya yang menguasai hukum Islam. ${ }^{16}$

Dengan demikian, perbedaan penafsiran terhadap kompetensi peradilan agama tidak perlu lagi dijadikan kendala utama dalam menyelesaikan perkara ekonomi syariah, sebab meskipun secara eksplisit penjelasan pada pasal 55 ayat (2) membuka ruang opsi penyelesaian perkara sesuai isi akad melalui musyawarah, mediasi perbankan, badan arbritase syariah dan peradilan umum, namun bila di cermati secara saksama, bunyi pasal 55 ayat 1 UUPS telah memberikan kompetensi absolut kepada peradilan agama. Bahkan, penyelesaian perkara ekonomi syariah tersebut menurut pasa 55 ayat 3 tidak boleh bertentangan dengan prinsip syariah. Menurut perspektif hukum normatif, proses litigasi penyelesaian perkara ekonomi syariah telah menjadi kompetensi absolut peradilan agama.

Pendapat penulis diatas sejalan dengan pendapat Abdul Gani Abdullah. Ia menegaskan bahwa teori lex posteriori derogat legi priori tidak dapat diberlakukan

16 Hasbi Hasan, Menyoal Kompetensi Peradilan Agama dalam Penyelesaian Perkara Ekonomi Syariah, dalam jurnal Mimbar Hukum dan Peradilan Edisi Nomor 73 tahun 2011, hal. 134. 
terhadap UU No 3 Tahun 2006, sebab UU No 21 Tahun 2008 yang memberikan peluang kepada peradilan umum untukmenyelesaikan perkara ekonomi syariah sesuai dengan isi akad, tidak dalam posisi yang sama; Peradilan agama ditempatkan pada posisi litigasi, sementara peradilan umum ditempatkan pada posisi non litigasi. Seperti sertifikat hak Milik yang datang lebih dahulu tidak dapat membatalkan sertifikat yang datang kemudian bagi objek yang sama.

Dengan argumen yang sama, asas lex specialis derogat lex generalisjuga tidak dapat diberlakukan terhadap UU No 3 tahun 2006, karena asas lex specialis derogat lex generalis hanya berlaku untuk rezim hukum yang sama dan sederajat. UU No 3 tahun 2006 adalah Undang-Undang tentang perubahan atas UU No 7 tahun 1989 tentang peradilan agama, sementara UU No 21 tahun 2008 adalah Undang-Undang tentang perbankan syariah. Jadi, dua Undang-Undang yang berada dalam rezim hukum yang berbeda. Undang-Undang peradilan agama adalah Undang-Undang spesialis dari undang-undang kekuasaan kehakiman, sementara undang-undang perbankan syariah merupakan spesialis undangundang perbankan. Karena menyangkut dua hal yang berbeda, maka dalam hal ini tidak berlaku asas lex specialis derogat lex generalis. Dengan demikian, UU No 21 tahun 2008 tidak dapat mengesampingkan UU No 3 tahun 2006, apalagi memindahkan kompetensi absolut peradilan agama ke peradilan lain.

Dengan demikian, menurut analisis teoretis diatas, frasa pengadilan dalam lingkungan peradilan umum yang di posisikan dalam kelompok non litigasi dapat dikesampingkan oleh hakim, karena penyelesaian cara itu berada diluar litigasi atau diluar pengadilan. Tafsir yuridis ini berarti perkara perbankan syariah untuk berlitigasi ada pada pengadilan dalam lingkungan peradilan agama. ${ }^{17}$

Undang-Undang Nomor 7 Tahun 1989 tentang Peradilan Agama telah mengalami dua kali perubahan, yaitu melalui Undang-Undang Nomor 3 Tahun 2006 tentang Perubahan atas Undang-Undang Nomor 7 Tahun 1989 tentang Peradilan Agama dan Undang-Undang Nomor 50 Tahun 2009 tentang Perubahan kedua atas Undang-Undang Nomor 7 Tahun 1989 tentang Peradilan Agama. Beberapa perubahan penting adalah:

Pengadilan khusus dalam lingkungan Peradilan Agama adalah pengadilan syariah Islam yang diatur dengan Undang-Undang. Mahkamah Syar'iyah di

17 Ibid Hasbi, Menyoal hal. 136. 
Provinsi Nanggroe Aceh Darussalam yang dibentuk berdasarkan UndangUndang Nomor 18 Tahun 2001 tentang Otonomi Khusus bagi Provinsi Daerah Istimewa Aceh sebagai Provinsi Nanggroe Aceh Darussalam yang oleh Undang-Undang Nomor 4 Tahun 2004 tentang Kekuasaan Kehakiman Pasal 15 ayat (2) disebutkan bahwa: Peradilan Syari' ah Islam di Provinsi Nanggroe Aceh Darussalam merupakan pengadilan khusus dalam lingkungan peradilan agama sepanjang kewenangannya menyangkut kewenangan peradilan agama, dan merupakan pengadilan khusus dalam lingkungan peradilan umum sepanjang kewenangannya menyangkut kewenangan Peradilan Umum.Perubahan dalam pasal ini menunjukkan bahwa kekuasaan Peradilan Agama sesungguhnya sudah lebih luas dengan telah diberlakukannya peradilan khusus di Nangroe Aceh Darussalam yang telah menerapkan hukum pidana, meskipun dalam prakteknya masih terbatas pada perkara hudud dan ta'zir. ${ }^{18}$

Kewenangan Mengadili Tidak Meliputi Sengketa Hak Milik Atau Sengketa Lain Antar Orang Islam dengan Non Islam (Pasal 50)

Apabila terjadi sengketa hak milik atau sengketa lain dalam perkara yang menjadi kewenangan Peradilan Agama cara penyelesaiannya adalah sebagai berikut.

a. Apabila objek sengketa terdapat sengketa hak milik atau sengketa lain antara orang Islam dengan selain orang Islam maka menjadi kewenangan Peradilan Umum untuk memutuskan perkara tersebut. Proses pemeriksaan perkara di Peradilan Agama terhadap objek sengketa yang masih terdapat sengketa milik atau sengketa lain antara orang Islam dan selain orang Islam ditunda terlebih dahulu sebelum mendapatkan putusan dari Peradilan Umum. Sebagaimana diatur dalam pasal 50 (1) Undang-Undang No.3 Tahun 2006.

“Dalam hal terjadi sengketa hak milik atau sengketa lain dalam perkara sebagaimana dimaksud dalam pasal 49, khusus mengenai objek sengketa tersebut harus diputus lebih dahulu oleh pengadilan dalam lingkungan Peradilan Umum"

b. Apabila objek sengketa terdapat sengketa hak milik atau sengketa lain antara orang Islam maka Peradilan Agama dapat memutus bersama-sama perkara yang menjadi kewenangan Peradilan Agama sebagaimana diatur

18 Ibid Ali, Sejarah...,hal. 188. 
dalam pasal 50 (1) Undang-Undang No.3 Tahun 2006

Apabila terjadi sengketa hak milik sebagaimana dimaksud ayat (1) yang subjek hukumnya antara orang-orang yang beragama Islam, objek sengketa tersebut diputus oleh Pengadilan Agama bersama-sama perkara sebagaimana dimaksud dalam pasal $49 .{ }^{19}$

Tambahan lain tentang kewenangan peradilan agama adalah bahwa Pengadilan Agama memberikan itsbat kesaksian rukyat hilal dalam penentuan awal bulan pada tahun Hijriyah, hal ini diatur dalam Pasal 52 Undang-Undang no. 3 tahun 2006. Pengadilan agama juga dapat memberikan keterangan atau nasehat mengenai perbedaan penentuan arah kiblat dan penentuan waktu shalat.

Perkembangan kewenangan tersebut terkait erat dengan kesiapan aparat, termasuk hakim dan panitera. Pemahaman hakim tentang ekonomi syari'ah mutlak diperlukan. Oleh karena hadirnya Undang-Undang no.3 tahun 2006 diharapkan dapat memberikan inspirasi para penegak hukum di lingkungan Peradilan Agama untuk lebih meningkatkan kinerja dan kualitas sumber dayanya dalam rangka memberikan pelayanan publik di bidang hukum secara optimal. ${ }^{20}$

\section{F. Penutup}

Kompetensi Peradilan Agama telah mengalami dinamika yang cukup pelik serta mengarah pada pasang surut. Kendati tidak sampai dihapuskan, namun lingkup yurisdiksi peradilan agama kerap dibatasi pada perkara keperdataan tertentu. Kenyataan ini sesungguhnya tidak terlepas dari kehendak politik (political will) para penguasa pada masanya yang tercermin dalam kebijakankebijakan yang ditempuh oleh penguasa bersangkutan. Tak dapat dipungkiri bahwa faktor dinamika politik hukum dan kehendak politik penguasa dari masa ke masa telah menggoreskan catatan penting bagi eksistensi, kedudukan, dan kewenangan peradilan agama di Indonesia, yang dalam kenyataannya tidak selalu berada dalam perjalanan yang relatif mulus.

Sungguhpun begitu, pada akhirnya kebijakan regulasi dan politik hukum

19 Pasal 50 (1) Undang-Undang No 3 Tahun 2006 tentang Perubahan Undang-Undang No 7 Tahun 1989 tentang Peradilan Agama.

20 Mardani, Hukum Islam, (Yogyakarta: Pustaka Pelajar, 2015),hlm, 194. 
negara dapat menempatkan posisi peradilan agama dalam sistem peradilan nasional secara lebih proporsional. Fakta fluktuasi dan instabilitas pencitraan peradilan agama dalam dinamika politik hukum dan kehendak politik pemerintah kadangkala menunjukkan apresiasi negatif dan kadangkala juga positif. Konfigurasi dialektika peradilan agama antara peluang dan tantangan yang niscaya saling bersitegang itu, utamanya muncul dalam bentuk pro dan kontra atas berbagai kebijakan regulasi. Satu diantaranya terkait dengan status, kedudukan, dan kewenangannya dalam sistem peradilan nasional.

Secara historis sosiologis, kompetensi peradilan agama pada dasarnya sangat terpaut erat dengan pelaksanaan hukum Islam sebagai hukum yang hidup di masyarakat (living law). Sekalipun demikian sejak munculnya teori resepsi produk Christian Hurgronje, kompetensi peradilan agama pernah dibatasi, tidak lagi mengalami masalah waris, karena dianggap belum menjadi hukum adat. Berdasarkan pengaruh teori, kompetensi peradilan agama hanya diperkenankan untuk menangani masalah perceraian, nafkah, talak, dan rujuk.

Kompetensi peradilan agama di Indonesia sesungguhnya sangat terkait erat dengan persoalan kehidupan umat Islam, karena ia menjadi sui generisnya. Namun, karena Indonesia bukan negara Islam, maka kompetensi peradilan agama tidak menyangkut seluruh persoalan umat Islam melainkan hanya terkait dengan persoalan hukum keluarga (ahwa al-syakhsiyyah) ditambah beberapa persoalan muamalah.

Perubahan kompetensi mulai tampak dalam UU nomor 1 tahun 1974 yang meliputi persoalan, penentuan keabsahan anak, perwalian, penetapan asal usul anak, dan izin menikah. Tidak sebatas itu, kompetensi peradilan agama juga bertambah ketika keluar PP nomor 28 tahun 1977 tentang perwakafan tanah milik, terutama dalam ketentuan Pasal 12. Bahkan, pada 1989, kompetensi peradilan agama kembali mendapatkan perluasan, tidak lagi sebatas masalah perkawinan, namun juga masalah kewarisan, wasiat, hibah, wakaf dan sedekah. Ketentuan tersebut dinyatakan dalam UU nomor 7 tahun 1989 tentang peradilan agama. Kemunculan undang-undang ini tidak saja memberikan keleluasaan kompetensi akan tetapi juga telah memberikan kemandirian kepada peradilan agama sebagai pelaksana kekuasaan kehakiman, sehingga peradilan agama mulai mempunyai hukum acara sendiri, dapat melaksanakan keputusannya 
sendiri, mempunyai juru sita sendiri, serta mempunyai struktrur dan perangkat yang kuat berdasarkan undang-undang. Kemudian, undang-undang peradilan agama nomor 7 tahun 1989 mengalami perubahan dengan undang-undang nomor 3 tahun 2006 tentang perubahan atas undang-undang nomor 7 tahun 1989. Kompetensi absolut pengadilan agama bertambah pada undang-undang ini yaitu, pengadilan agama mempunyai wewenang untuk mengadili sengketa ekonomi syariah (Pasal 49) dan mempunyai Pengadilan Khusus untuk wilayah Propinsi Daerah Nanggroe Aceh Darussalam (Pasal 3A). Selanjutnya undangundang nomor 3 tahun 2006 diubah kembali dengan undang-undang nomor 50 tahun 2009 tentang perubahan kedua atas undang-undang nomor 7 tahun 1989.

\section{DAFTAR PUSTAKA}

Anshori, Abdul Ghofur, 2007. Peradilan Agama di Indonesia Pasca UU No. 3 Tahun 2006; Sejarah, Kedudukan, dan Kewenangan. Yogyakarta: UII Press.

Firdawaty, Linda Analisis tentang perubahan undang-undang Peradilan Agama, dalam Jurnal AL-'adalah, Vol. x, No. 2 Juli 2011.

Hasan, Hasbi. 2011. Menyoal Kompetensi Peradilan Agama dalam Penyelesaian Perkara Ekonomi Syariah, dalam jurnal Mimbar Hukum dan Peradilan Edisi Nomor 73.

Irfan, Ali, Sejarah, Peran dan Kewenangan Peradilan dalam penegakan Hukum Islam di Indonesia, makalah disampaikan pada seminar nasional dan call for papers "perkembangan Hukum Islam di Indonesia, Penyelenggara bagian Hukum Perdata Fakultas Hukum Universitas Diponegoro Semarang, tanggal 19 September 2012.

Lubis, Sulaikin dkk, 1995. Hukum Acara Perdata Peradilan Agama di Indonesia. Jakarta: Prenada Media.

Manan, Abdul, 2005. Penerapan Hukum Acara Perdata di Lingkungan Peradilan Agama. Jakarta: Prenada Media.

Mardani, 2015. Hukum Islam. Yogyakarta: Pustaka Pelajar.

Nurhayani, Neng Yani. 2015. Hukum Acara Perdata, Pustaka Setia, Bandung.

Sumitro, Warkum. 2005. Perkembangan Hukum Islam di tengah Kehidupan sosial politik di Indonesia, Malang, Bayu Media Publishing. 
Rasyid, Royhan A.1992. Hukum Acara Peradilan Agama, Jakarta: Raja Grapindo Persada.

Rasaid, M. Nur. 1996. Hukum Acara Perdata, Sinar Grafika, Jakarta.

Tono, Sidiq, 1997. "Perkembangan Peradilan di Indonesia: Studi Politik Hukum", dalam Jurnal Al Mawarid. Edisi VI Desember. Yogyakarta: Fakultas Ilmu Agama Islam.

Wibowo, Ari. 2007. Perkembangan Eksistensi Peradilan Agama di Indonesia Menuju ke Peradilan Satu Atap, dalam Jurnal al-Mawarid vol. XVII. 
362 Millah Vol. XVI, No. 2, Februari 2017 